\title{
PENGEMBANGAN APLIKASI MEDIA KOMUNIKASI BADAN PENGAWAS PEMILU REPUBLIK INDONESIA BERBASISKAN WEB DAN WAP
}

\author{
Alex Chandra; Tonny Lion Kencana; Yurri Kurnianingsi; Elidjen \\ Computer Science Department, School of Computer Science, Binus University \\ Jl. K.H. Syahdan No. 9, Palmerah, Jakarta Barat 11480 \\ elidjen@binus.edu
}

\begin{abstract}
The research objective is to develop Web-based and WAP-based communiaction media applications to facilitate communication between the Board of Election Supervisors of Republic of Indonesia (Bawaslu RI) with all stakeholders associated with the public election. The research method used are analysis and design Methods. Analysis includes system analysis, identification of information needs, and the analysis of existing websites. The results of this analysis are used to design the applications of the proposed system of communication media. The design is implemented for database design and structured web-based and WAP-based applications. This research obtains Web-based and WAP-based communiaction media applications that facilitate communication about everything related to the public election.
\end{abstract}

Keywords: communication media, web, WAP, Boards of Election Supervisory, public election

\begin{abstract}
ABSTRAK
Tujuan penelitian ialah mengembangkan aplikasi media komunikasi berbasis Web dan WAP yang dapat memudahkan komunikasi antara Badan Pengawas Pemilu Republik Indonesia (Bawaslu RI) dengan semua pemangku kepentingannya yang terkait dengan Pemilu. Metode penelitian yang digunakan dalam penulisan penelitian yaitu analisis dan perancangan. Analisis meliputi analisis sistem, identifikasi kebutuhan informasi, dan analisis website yang ada. Hasil analisis ini digunakan untuk merancang aplikasi media komunikasi sistem yang diusulkan. Perancangan meliputi perancangan database dan aplikasi berbasis web dan WAP secara terstruktur. Hasil yang dicapai berupa aplikasi media komunikasi berbasis Web dan WAP yang mempermudah komunikasi mengenai segala sesuatu yang terkait dengan pemilu.
\end{abstract}

Kata kunci: media komunikasi, web, WAP, Bawaslu RI, pemilu 


\section{PENDAHULUAN}

Badan Pengawas Pemilihan Umum Republik Indonesia (Bawaslu RI) adalah lembaga resmi pemerintah yang berkedudukan di Ibu Kota Negara yang bertugas mengawasi penyelenggaraan Pemilu di seluruh wilayah Negara Kesatuan Republik Indonesia (NKRI). Bawaslu RI bertugas mengurus segala sesuatu yang berhubungan dengan pemilu yang ada di Indonesia, baik pemilu yang diadakan di kecamatan, kabupaten/kota, maupun provinsi. Dalam melaksanakan tugas-tugasnya Bawaslu RI dibantu Panitia Pengawas Pemilu (Panwaslu). Panwaslu dibagi menjadi tiga bagian sesuai dengan wilayah fungsionalnya yaitu Panwaslu Kecamatan, Panwaslu Kabupaten / Kota, dan Panwaslu Provinsi. Selain itu masyarakat pun dapat menyampaikan berbagai informasi pelanggaran yang mungkin terjadi kepada Bawaslu RI atau melalui Panwaslu.

Keberadaan Panwaslu yang tersebar di kecamatan, kabupaten/kota, dan propinsi dan keterbukaan Bawaslu RI terhadap laporan terkait pelanggaran penyelanggaraan pemilu sangat membutuhkan sarana komunikasi yang mudah dilakukan dan ekonomis. Demikian juga dengan pentingnya deseminasi informasi yang up-to-date kepada berbagai pihak yang terkait dalam pemilu semakin memperkuat kebutuhan sarana komunikasi yang mudah dilakukan dan ekonomis. Sarana berkomunikasi melalui peralatan elektronik seperti telepon, mobile phone, dan email sudah dilakukan untuk meningkatkan koordinasi dalam mendukung kinerja yang optimal dalam tugas pengawasan pemilu. Untuk lebih memudahkan deseminasi informasi yang masif, mudah, dan ekonomis, masih diperlukan sarana komunikasi lainnya berupa aplikasi media komunikasi berbasis Web dan WAP. Website adalah keseluruhan halaman-halaman web yang terdapat dalam sebuah domain yang mengandung informasi. Sebuah website biasanya dibangun atas banyak halaman web yang saling berhunbungan, Hubungan antara satu halaman we dengan halaman web yang lainnya disebut dengan hyperlink, sedangkan teks yang dijadikan media penghubung disebut hypertext (Mooduto dan Hidayat, 2009). Sementara WAP pada dasarnya adalah suatu tumpukan protokol yang mampu mengakses Web (Tanenbaum, 2003). Bearer layer adalah lapisan paling bawah yang mampu mendukung semua sistem mobile phone yang ada seperti GSM (Global Systems for Mobile Communications), CDMA (Code Digital Multiple Access), GPRS (General Pocket Radio Services), dan lain sebagainya.

Ruang lingkup penelitian difokuskan dan diarahkan pada pengembangan aplikasi media komunikasi berbasis Web dan WAP yang menyediakan informasi mengenai pemilu dengan berbagai fitur yang memudahkan komunikasi Bawaslu RI baik dengan Panwaslu dan berbagai pihak yang terkait dalam pemilu. Selain itu aplikasi juga dirancang untuk memudahkan deseminasi informasi yang dibutuhkan guna meningkatkan kinerja pemantauan pemilu.

Tujuan penelitian untuk menganalisis aplikasi media komunikasi berbasis Web yang ada di Bawaslu dan merancang aplikasi media komunikasi berbasis Web yang lebih baik dan merancang aplikasi baru berbasis WAP untuk memberikan akses yang sebesar-besarnya kepada masyarakat untuk mengakses berbagai informasi pemilu dan berperan aktif melaporkan berbagai pelanggaran pemilu. Manfaat yang diperoleh dari perancangan aplikasi media komunikasi berbasis Web dan WAP dapat membantu memudahkan komunikasi, koordinasi, deseminasi informasi dari dan ke Bawaslu dengan efektif dan efisien.

\section{METODE}

Metodologi yang digunakan dalam penulisan skripsi ini meliputi dua bagian pokok, yaitu metode analisis dan metode perancangan. 
Analisis website dan WAP dibagi dalam 2 tahap, yaitu survei terhadap media yang sedang berjalan dan analisis terhadap website dan WAP tersebut. BAWASLU RI merupakan suatu lembaga pemerintah yang mengurusi masalah penyalahgunaan hak suara ataupun pelanggaran lainnya dalam pemilu. Oleh karena itu, alangkah baiknya bila suatu website merupakan website interaktif dan terdapat sebuah WAP yang akan sangat berperan dalam penyediaan informasi. Website yang dibuat akan lebih user friendly dan lebih interaktif dari website sebelumnya, sementara WAP akan memiliki fungsi utama memberi update terbaru dari berita-berita sehingga dapat bermanfaat untuk masyarakat umum.

Metode perancangan yang digunakan adalah metode waterfall (Gambar 1). Metode ini ditemukan oleh Roger S. Pressman. Konsep ini muncul pada tahun 1970 sehingga sering dianggap kuno, tetapi merupakan model yang paling banyak dipakai didalam Software Engineering (SE). Model ini juga disebut Classic Life Cycle. Model ini melakukan pendekatan secara sistematis dan urut mulai dari level kebutuhan sistem lalu menuju ke tahap analisis, desain, coding, testing / verification, dan maintenance. Disebut dengan waterfall karena tahap demi tahap yang dilalui harus menunggu selesainya tahap sebelumnya dan berjalan berurutan. Sebagai contoh tahap desain harus menunggu selesainya tahap sebelumnya yaitu tahap requirement.

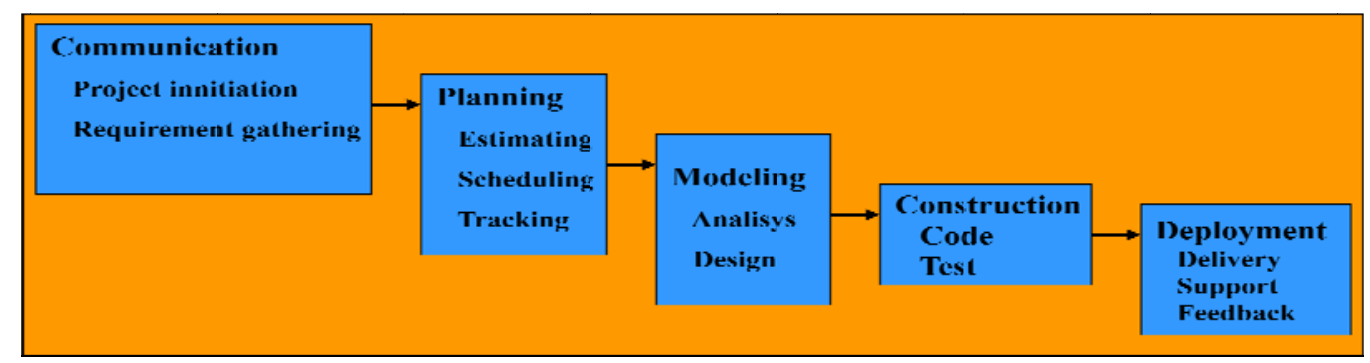

Gambar 1 Waterfal Model (Pressman)

\section{HASIL DAN PEMBAHASAN}

\section{Sistem yang Sedang Berjalan}

BAWASLU RI merupakan badan pemerintah yang berkedudukan di Ibu Kota Negara. BAWASLU RI bertugas mengurus segala sesuatu yang berhubungan dengan pemilu yang ada di Indonesia, baik pemilu yang diadakan di kecamatan, kabupaten / kota, maupun provinsi. Dalam melaksanakan tugas-tugasnya, BAWASLU RI memiliki Panwaslu, dimana Panwaslu adalah panitia pengawas pemilu yang juga merupakan badan pemerintahan yang mendukung BAWASLU RI. Panwaslu dibagi menjadi tiga bagian sesuai dengan wilayah fungsionalnya yaitu Panwaslu Kecamatan, Panwaslu Kabupaten / Kota, dan Panwaslu Provinsi.

Pemilu yang akan dilaksananakan telah memiliki jadwal yang telah ditentukan dan Panwaslu memiliki jadwal pemilu ini, dimana setiap informasi dari Panwaslu akan disampaikan ke BAWASLU RI. Setiap informasi yang telah disampaikan dan informasi yang ada pada BAWASLU RI dinilai perlu untuk disampaikan kepada masyarakat. Cara penyampaian informasi yang selama ini dilakukan adalah melalui media konvensional seperti koran dan radio lokal. Selain itu, BAWASLU RI juga telah menggunakan website sebagai media untuk menyampaikan informasi, namun website yang digunakan ternyata sukar untuk dimengerti dan tidak efektif. WebSite ini sukar untuk dimengerti karena website yang digunakan ini memiliki tingkat kompleksitas yang tinggi, terlihat dari banyaknya menu yang ada, akan tetapi tidak efektif karena adanya beberapa submenu website yang tidak berfungsi dengan baik. 
Data mengenai informasi yang disediakan pada website didapatkan melalui hasil rapat yang diadakan secara berkala sesuai jenis rapat yang dilaksanakan oleh BAWASLU RI, dimana jenis rapat tersebut antara lain: rapat pleno, rapat teknis, rapat koordinasi, rapat koordinasi pengawasan, dan rapat lingkup sekretariat. Rapat pleno, rapat teknis, dan rapat koordinasi dilaksanakan paling sedikit 1 kali dalam 1 minggu, sedangkan rapat koordinasi pengawasan dan rapat lingkup sekretariat dilaksanakan sesuai kebutuhan dan kepentingan pengawasan penyelenggaraan Pemilu Kada. Lalu pada website yang digunakan ini, belum terdapat fitur pengaduan, selama ini pengaduan hanya dilakukan dengan menggunakan SMS, dan ditindaklanjuti oleh bagian hukum, humas, dan partisipasi masyarakat, akan tetapi pengaduan ini tidak dapat diketahui oleh masyarakat lainnya, selain masyarakat yang melakukan pengaduan. Oleh karena itu, walaupun BAWASLU RI telah memiliki website sebagai media penyampaian informasi, tetapi ternyata tidak semua informasi yang ingin disampaikan dapat disampaikan, contohnya adalah pengaduan. Selain itu masyarakat juga masih kesulitan dalam mengakses informasi. Hal ini dikarenakan belum semua kalangan masyarakat memiliki komputer ataupun jaringan internet sebagai media untuk mengakses website yang ada.

\section{Permasalahan yang dihadapi}

Setelah menganalisis sistem yang sedang berjalan pada BAWASLU RI, saatnya untuk merangkum permasalahan berdasarkan hasil kuesioner yang telah disebarkan pada beberapa orang yang mengenal atau pun yang tidak mengenal BAWASLU RI. Maka diperoleh masalah sebagai berikut: Informasi/ pengumuman tentang hasil Pemilu belum tentu sampai ke telinga masyarakat, sulit untuk memahami dan mengerti isi website sepenuhnya, adanya beberapa menu pada website yang tidak berjalan, kurang efektifnya website BAWASLU RI yang ada saat ini, tidak semua masyarakat memiliki komputer dan memiliki jaringan internet, dan dibutuhkan aplikasi lain yang lebih mudah untuk diakses oleh masyarakat.

\section{Solusi yang ditawarkan}

Dari hasil analisis permasalah yang telah disebutkan di atas, dapat diketahui bahwa dibutuhkan sebuah sistem yang mampu membantu penyampaian informasi. Sistem tersebut berupa aplikasi website dan WAP Site yang merupakan media yang efektif dan mudah dimanfaatkan oleh berbagai pihak dalam menyampaikan informasi.

Aplikasi website yang dibuat berbasis PHP dan memanfaatkan javascript sebagai pendukung aplikasi, memanfaatkan MySQL sebagai media penyimpanan database, memanfaatkan Dreamwaver sebagai media perancangan, dan XAMPP version2.2 sebagai localhost untuk menjalankan website. Di dalamnya ada beberapa fasilitas yang mendukung proses penyampaian informasi, antara lain: (1) fasilitas untuk menyampaikan informasi atau berita terbaru yang dapat diupdate setiap saat; (2) fasilitas bagi user (rakyat luas) berupa berbagai file hukum terkait masalah pemerintahan dan perihal yang dapat di-download langsung dari website; (3) fasilitas bagi user berupa sebuah menu FAQ yang lebih jelas dan efektif, serta selalu di-update demi memenuhi keingintahuan user mengenai Pemilu dan BAWASLU RI; (4) fasilitas bagi user untuk menyampaikan pengaduan seputar Pemilu, Pemilu Kada atau pun mengenai pihak-pihak yang berkaitan seperti Panwaslu dan Bawaslu sekali pun; (5) fasilitas votting seputar website BAWASLU RI untuk mengetahui sejauh mana perbaikan atau penambahan perlu dilakukan terhadap website; (6) menyediakan fasilitas login mail untuk mempermudah user mengecek email secara mudah dan cepat; (7) perancangan aplikasi yang mudah diakses dan dipahami kalangan umum dengan membuat perancangan interface yang lebih menarik dan user friendly. Salah satu contohnya adalah penyajian link ke lembaga pemerintahan terkait dalam bentuk tag-cloud. Di bawah ini kami sertakan perbandingan antara website yang sedang berjalan dengan website yang menjadi usulan pemecahan masalah (Tabel 1). 
Tabel 1Perbandingan antara Website yang Sedang Berjalan dengan Website yang Diusulkan

\begin{tabular}{|c|c|}
\hline Website yang sedang Berjalan & Website Usulan Pemecahan \\
\hline $\begin{array}{l}\text { (1). Website memiliki tampilan yang kurang } \\
\text { menarik, baik dari sisi kombinasi warna atau } \\
\text { pun banner yang digunakan; } \\
\text { (2). Penyusunan menu dan submenu masih kurang } \\
\text { terstruktur sehingga sulit menemukan } \\
\text { informasi yang ingin diketahui; } \\
\text { (3). Menu pengaduan tidak berfungsi (tidak ada } \\
\text { form untuk mengisi pengaduan dan data } \\
\text { pengadu) padahal pengaduan secara online } \\
\text { merupakan perihal penting yang dibutuhkan; } \\
\text { (4). Menu FAQ tidak menampilkan informasi } \\
\text { sama sekali, hanya menampilkan fitur untuk } \\
\text { menampilkan arsip, akan tetapi ketika } \\
\text { dimanfaatkan tetap tidak ada arsip yang } \\
\text { ditampilkan; } \\
\text { (5). Adanya fitur kompleks yang malah } \\
\text { membingungkan pengguna website, misalnya } \\
\text { fitur untuk menampilkan arsip produk hukum } \\
\text { yang dibagi menjadi banyak jenis pencarian } \\
\text { menurut waktu (tanggal, bulan dan tahun) } \\
\text { akan tetapi hasilnya ditampilkan hampir selalu } \\
\text { "Tidak ada data”; } \\
\text { (6). Link untuk ke alamat website lembaga } \\
\text { pemerintah terkait ditampilkan berbentuk } \\
\text { linked text; } \\
\text { (7). Tidak adanya fitur untuk meminta penilaian } \\
\text { pengguna website akan perkembangan } \\
\text { website. }\end{array}$ & $\begin{array}{l}\text { (1). Website menggunakkan banner baru yang } \\
\text { lebih menarik dan perpaduan kombinasi } \\
\text { warna yang menarik serta memberi kesan } \\
\text { modern; } \\
\text { (2). Penyusunan menu dan submenu dibuat lebih } \\
\text { terstruktur sehingga mudah dalam } \\
\text { menemukan informasi yang ingin diketahui; } \\
\text { (3). Mengoptimalkan menu pengaduan, } \\
\text { menyediakan form pengisian pengaduan yang } \\
\text { disertai data pengadu dan menampilkan } \\
\text { pengaduan yang layak ditampilkan beserta } \\
\text { jawaban; langsung menampilkan } \\
\text { (4). Menu FAQ } \\
\text { keseluruhan informasi yang ada mengenai } \\
\text { pertanyaan yang sering kali ditanyakan } \\
\text { beserta jawabannya secara detail; } \\
\text { (5). Lebih memanfaatkan fitur search sederhana } \\
\text { yang berfungsi optimal untuk menampilkan } \\
\text { data dibanding fitur kompleks yang tidak } \\
\text { mampu berfungsi optimal seperti pada fitur } \\
\text { untuk menampilkan arsip produk hukum } \\
\text { karena arsip - arsip tersebut tidak selalu ada } \\
\text { per tahunnya; } \\
\text { (6). Link untuk ke alamat website lembaga } \\
\text { pemerintah terkait disajikan dalam bentuk } \\
\text { linked text dan tag-cloud; } \\
\text { (7). Penyediaaan fitur voting seputar penilaian } \\
\text { website untuk menunjang perkembangan lebih } \\
\text { jauh pada website BAWASLU RI. }\end{array}$ \\
\hline
\end{tabular}

Aplikasi WAP Site yang akan dibuat akan menggunakan bahasa pemrograman WML dan memanfaatkan Openwave version 7 yang membantu membuat interface yang lebih modern tetapi tetap sederhana. Di dalamnya ada pun beberapa fasilitas yang mendukung proses penyampaian informasi, antara lain: (1) fasilitas untuk menyampaikan headline berita terbaru yang dapat di-update dengan cepat; (2) fasilitas bagi user berupa sebuah menu FAQ yang paling sering ditanyakan dan ingin diketahui rakyat luas yang dapat dibuka di handphone; (3) fasilitas bagi user untuk menyampaikan pengaduan melalui handphone seputar Pemilu, Pemilu Kada atau pun mengenai pihak-pihak yang berkaitan seperti Panwaslu dan Bawaslu sekali pun; (4) perancangan aplikasi yang mudah diakses, ekonomis dan mudah dipahami kalangan umum dengan membuat perancangan interface yang lebih user friendly.

\section{Prototipe Sistem}

\section{Perancangan Menu Website}

Pada website BAWASLU RI terdapat beberapa menu (Gambar 2) yang dapat diakses user, yaitu: (1) Beranda - user dapat melihat update terbaru seputar pemilu, BAWASLU RI, dan pemerintahan, baik berupa berita, foto-foto, headline kegiatan penting yang akan berjalan; (2) Berita informasi yang pernah dikeluarkan oleh BAWASLU RI, dari yang terbaru hingga yang terlama sekali pun; (3) Profil Bawaslu -informasi seputar submenu yang ada, yaitu Sekilas Bawaslu, Rencana Strategis Bawaslu, Struktur Bawaslu, Profil Anggota; (4) Produk Hukum - informasi seputar submenu 
yang ada, yaitu Amar Putusan, TAP MPR, Undang - Undang, Peraturan Pemerintah, Peraturan Presiden, Peraturan Bawaslu, Surat Edaran Bawaslu, MOU; (5) Pengaduan - informasi pengaduan terhadap BAWASLU RI dan pengajuan pengaduan pada BAWASLU RI secara online; (5) Agenda informasi aktifitas seperti yang terdapat pada submenu, yaitu Kalender Kegiatan dan Jadwal Tahapan Pemilu Kada; (6) Informasi - hal-hal lain seperti yang terdapat pada submenu, yaitu Informasi Kinerja, Panwaslu, Press Release, Publikasi, Link Situs; (7) Lelang - pengumuman seputar lelang seperti yang terdapat pada submenu, yaitu Pengumuman Lelang dan Pengumuman Hasil Lelang; (8) Mail - akses mail user langsung dari website ketika sedang menelusuri website BAWASLU; (9) FAQ - jawaban sekaligus penjelasan mengenai perihal yang sering kali ditanyakan rakyat umum hanya dengan membaca halaman ini.

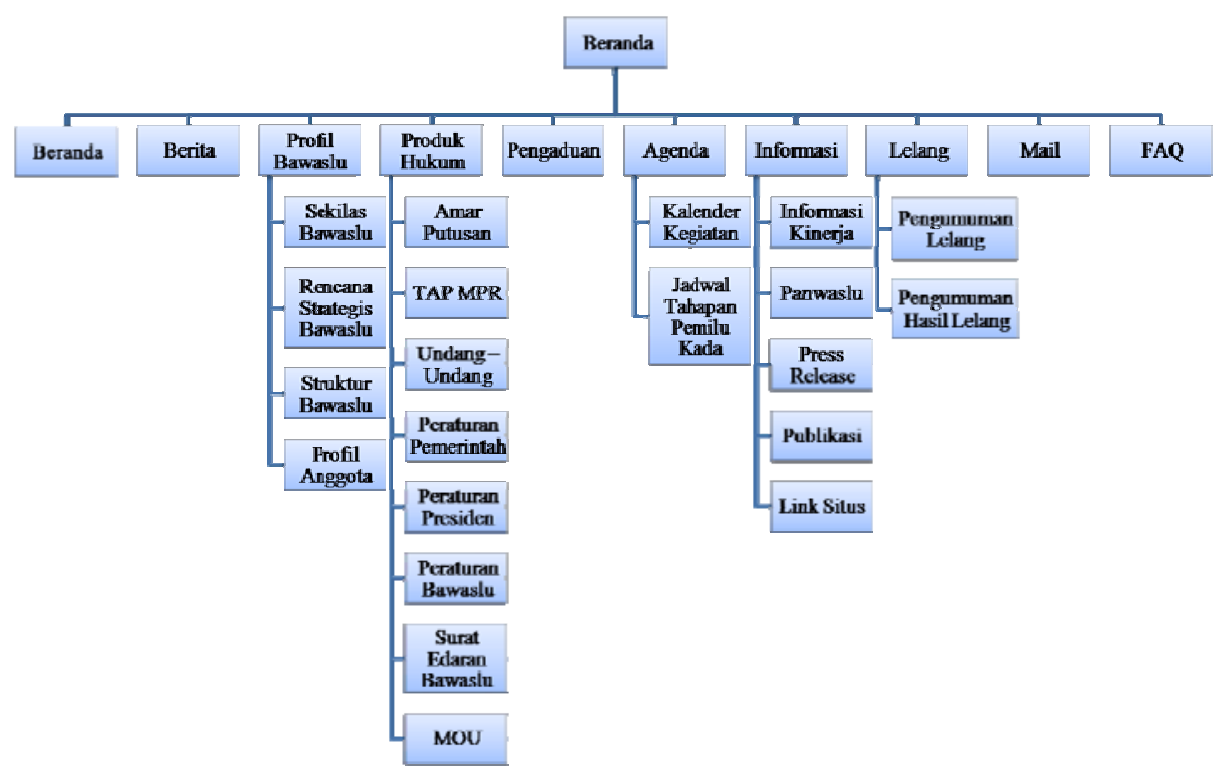

Gambar 2 Perancangan menu website BAWASLU RI

\section{Perancangan Menu WAP Site}

Pada WAP Site BAWASLU RI terdapat beberapa menu (Gambar 3) yang dapat diakses user, yaitu: (1) Beranda - headline berita-berita terbaru yang dikeluarkan oleh BAWASLU RI, tetapi tidak dapat dibaca secara lengkap dan detail; (2) Sekilas Bawaslu - sedikit keterangan mengenai BAWASLU RI, sekedar memberitahukan idenditas kepemilikan WAP site; (3) Agenda - headline mengenai agenda aktifitas yang akan segera berjalan dalam waktu singkat. Pemberitahuan agenda ini hanya sebagai pengingat ketika telah menjelang waktu aktifitas; (4) Pengaduan - informasi pengaduan terhadap BAWASLU RI (hanya yang terbaru saja) dan pengajuan pengaduan pada BAWASLU RI melalui handphone; (5) Sekretariat - alamat dan kontak sekretariat BAWASLU RI; (6) FAQ jawaban sekaligus penjelasan singkat akan tetapi esensial mengenai perihal yang sering kali ditanyakan rakyat umum.

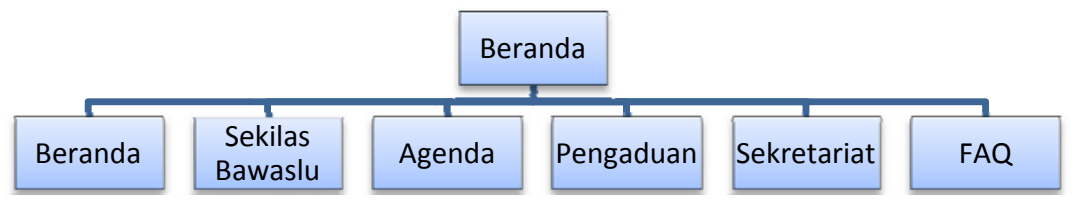

Gambar 3 Perancangan menu WAP site BAWASLU RI 


\section{Rancangan Antarmuka}

Menurut Shneiderman (2010, p88-89), sebuah sistem berbasis komputer selalu mempunyai elemen manusia yang terkait di dalamnya. Elemen manusia ini berinteraksi langsung dengan perangkat keras dan perangkat lunak melalui sebuah antarmuka (interface).

Gambar di bawah ini menunjukkan halaman beranda yang merupakan halaman pertama atau home (Gambar 4), ketika kita membuka website BAWALU RI. Pada halaman beranda ini, ditampilkan berita-berita yang terbaru pada BAWASLU RI, dengan menampilkan sedikit isi berita. Halaman ini juga ditampilkan dengan paging, sehingga memungkinkan tampilan menjadi lebih rapi dan lebih enak dilihat.

Halaman-halaman lain selain Beranda dapat dilihat dengan cara menekan link menu dan submenu yang terdapat di sebelah kiri. Sementara di sebelah kanan terdapat Gallery yang dapat menmpilkan foto-foto seputar kegiatan BAWASLU RI, Pemilu dan beberapa kegiatan yang menyangkut pemerintahan. Pada Gallery juga terdapat paging untuk mempermudah pengguna melihat foto-foto yang ada.

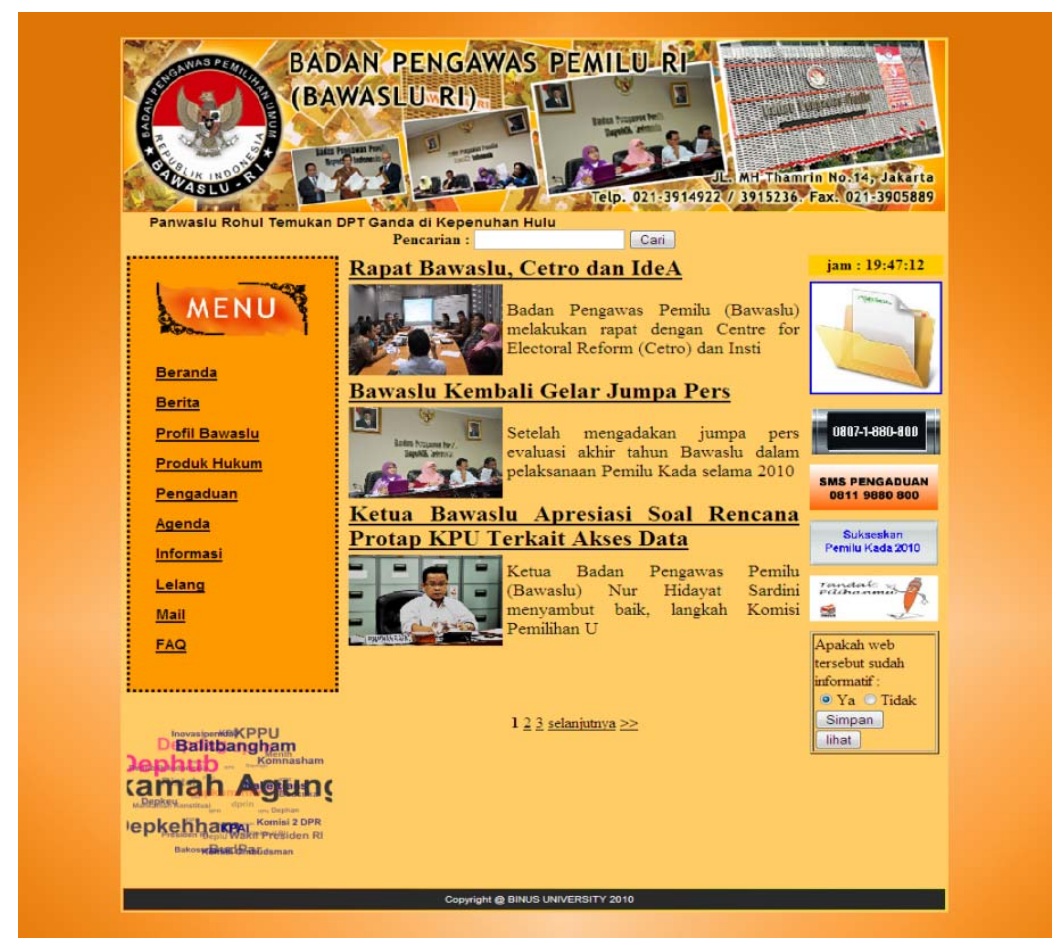

Gambar 4 Beranda website

Gambar 5 berikut merupakan halaman utama ketika user mengakses WAP site BAWASLU RI. Halaman ini berisi menu-menu diantaranya yaitu Beranda, Sekilas BAWASLU, Agenda, Pengaduan, Sekretariat, FAQ. Halaman-halaman lain dapat diakses pengguna WAP site dengan cara menekan link yang ada pada Menu Utama. 


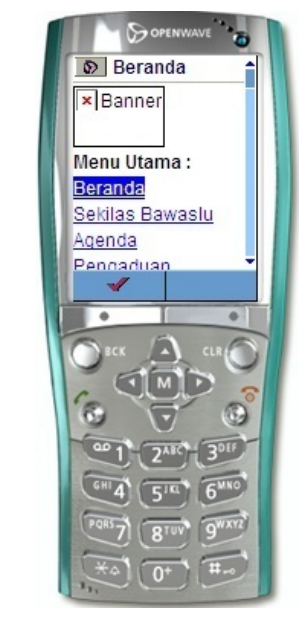

Gambar 5 Beranda WAP site

\section{PENUTUP}

Setelah melakukan analisis kebutuhan, perancangan, implementasi, dan evaluasi akan aplikasi yang dibuat penulis, dapat disimpulkan bahwa masalah yang sebelumnya ada pada system BAWASLU RI dapat diatasi dengan: penyusunan menu website yang lebih terstruktur, pengguna menjadi lebih mudah menemukan informasi yang perlu dan ingin diketahui, pembuatan fungsi menu secara optimal sehingga seluruh menu berjalan menyebabkan pengunjung website merasa puas dan tidak segan lagi mengakses informasi atau pun melakukan pengaduan pada website secara online, perubahan interface website BAWASLU RI, melalui pengelolaan interface baru yang lebih userfriendly dan terlihat modern, website mampu menarik perhatian masyarakat, penambahan fitur-fitur baru seperti tag-cloud dan voting pada website mampu menarik minat masyarakat untuk menelusuri website lebih jauh, dan pembuatan WAP site memudahkan masyarakat yang tidak memiliki atau sedang tidak di dekat komputer ataupun internet untuk mengakses informasi, yaitu melalui handphone.

Berikut ini adalah beberapa saran untuk pengembangan aplikasi lebih lanjut: melakukan maintenance berdasarkan pemantauan website dengan seksama, baik pengecekan attachment file, berita, image, maupun menu-menunya, dan melakukan update website berkala, meningkatkan fungsionalitas interaktif pada website, menambah jumlah web admin menjadi lebih dari dua orang untuk menunjang pengelolahan database yang terus menerus berkembang agar maintenance database terurus, meningkatkan keamanan website sehingga terbebas dari virus, hacker, spam, dan sebagainya, dan mengekspansi website dengan adanya forum tanya jawab sederhana untuk berdiskusi seputar pemilu, pemerintahan dan BAWASLU RI sehingga aspirasi masyarakat dapat tersampaikan.

\section{DAFTAR PUSTAKA}

Pressman, Roger S. (2010). Software Engineering: A Practicioner's Approach (7th edition). New York: McGraw-Hill.

Shneiderman, Ben. (2010). Designing the User Interface: Strategies for Effective Human-Computer Interaction (5th dition). New York: Addison-Wesley.

Tanenbaum, Andrew S. (2003). Computer Networks (4th edition). New Jersey: Pearson Education. 